\title{
A Case Study of Collaboration Among the ESP Practitioner, the Content Teacher, and the Students
}

\author{
Ana Almagro Esteban and Manuel C. Vallejo Martos \\ University of Jaén \\ aalmagro@ujaen.es
}

\begin{abstract}
The literature in the field of ESP (English for Specific Purposes) conspicuously documents the relevance of the collaboration between the teacher in this field and the content teacher, as well as that between the former and the student. However, the positions on this score are of a general nature and, consequently, cannot easily be put into practice. This has led us to analyze the main aspects determining this collaboration, and the way in which it can be implemented. In order to do so, we will take as a reference point a post-graduate course on Foreign Trade and, by extension, on Management Internationalization.

We start by describing the ESP teacher's profile, and following upon this, we introduce the theoretical framework of the present study. In turn, we give way to the contextualization of the course under scrutiny, which will allow us to describe how this collaboration was undertaken building upon Dudley-Evans and St John's (1998) view. Finally, we highlight the conclusion at which our paper has enabled us to arrive, namely, that the collaboration between both teachers builds progressively and that it has to be established by delimiting their role in it, that the students' collaboration always involves some risks we should assume and, finally, that teachers with a philological background have a great deal to bring to the ESP field.
\end{abstract}




\section{Introduction: Profile of the ESP practitioner}

The present analysis concerning the salient features that define the ESP (English for Specific Purposes) practitioner applies to those teaching-learning situations in which English is learnt as a foreign language. Consequently, English is not necessarily the mother tongue either of teachers or students (cf Voráèek [1987] as regards the different role of teachers whose native or second language is English, as well as that of the students, as opposed to contexts in which teachers are not native speakers of English, and the students learn English as a foreign language; also cf Gueye [1990] with respect to the ESP teacher's role in developing countries).

ESP teachers are almost always teachers of English for General Purposes, and their switch into this field is sudden (Strevens, 1988). As Donna (2000) explicitly mentions, they get by with some basic guidelines and with a little help which ultimately proves inappropriate. Their task is to analyze students' needs, outline objectives, select and adapt teaching materials, design lessons, create an adult-oriented learning environment, and assess students' progress (Schleppegrell, 1991). Although these might be the usual skills of teachers, and more precisely in the field of English teaching, the ESP teachers' role has still distinctive connotations, namely:

1) Needs are not defined according to the usefulness of English in our society, but, rather, in terms of a more immediate and real context than the teaching-learning situation, namely, the students' target situation. Therefore, needs are neither applicable to students in general (in this case we are faced with specialised students) nor to a wide spectrum.

2) Aims and objectives are not determined by external factors, what Strevens (1977:

145) terms general educational criteria, but by the students' profile.

3) Selection and adaptation of teaching materials means making use of all kinds of sources, among which the textbook is only one.

4) As a result, it is the teacher who teaches, and as Cunningsworth (1984) eloquently stresses, textbooks are good servants, but poor masters.

5) Students are not only adults, but also experts in their fields.

6) Students' assessment brings together proficiency in English and performance in their professional situation.

This general outline coincides with the six aspects upon which Dudley-Evans \& St John (1998) frame the ESP teacher's professionalism; that is to say, teacher, designer, provider of teaching materials, collaborator, researcher, and evaluator. On a similar note, Koh (1988), Robinson (1991), and Jackson (1998) coincide in showing that to the traditional tasks of an English teacher some other but less familiar tasks to an ESOL (English to Speakers of Other Languages) teacher must be added. This is the reason behind the term practitioner, instead of that of teacher, since it is the one which fits best the role of the ESP teacher, a role which goes beyond that of merely teaching (Dudley-Evans \& St John, 1998). In short, if homogeneity is the salient feature in teaching English for General Purposes, 
diversity is the defining criterion in the ESP field. Diversity is an element that demands versatility, as well as flexibility on the part of the teacher who seeks to be an effective practitioner of ESP. This versatility involves having a grasp of the students' field or professional context, as well as taking into consideration both the content teacher and the student as collaborators; some of these aspects will be discussed from a practical point of view in this paper.

All in all, it is not surprising that there is widespread agreement in the literature that the ESP teacher requires previous and additional training (cf Akermark [1983] regarding the competence required on the part of the practitioner of ESP in handling materials related to the students' field, a feature which is matter-of-fact for those working in this area, and that Schleppegrell [1991: 19] accurately observes: "[...] a good teacher of ESP requires more experience, additional training. [...] But the essential point is that becoming [sic] an effective teacher of ESP requires more experience, additional training, extra effort, a fresh commitment, compared with being a teacher of General English"). Similarly, it is a constant requirement that the ESP teacher should have distinctive personality traits and be experienced - a factor that we conceive from a teaching viewpoint - (Akermark, 1983; Dudley-Evans \& St John, 1988).

If this is the profile of ESP practitioners, their usual background generates controversy and opposing views: their linguistic and literary training might lead to the belief that teachers of ELT (English Language Teaching) are not the most appropriate for their lack of knowledge about Social Sciences, Science, and Technology; or as Strevens (1977: 159) notes: "There is a gap between the teachers and the taught, [...] and this can reduce the effectiveness of learning and teaching". This situation gets to such a point that newspaper job offers seem to restrict the ESP teacher's profile to the following aspects: "[...] to have an MA in Applied Linguistics, a year's experience of teaching in a developing country, and experience of materials writing" (Williams, 1981: 91). ${ }^{1}$

On the other hand, many are supportive of the view that ELT teachers have a great deal to contribute to the field of English for Specific Purposes (e.g. Akermark, 1983), as well as those stressing that their task is to teach language, not content pertaining to the students' field. In this sense, Jones' (1990: 91) words are particularly pertinent: "In many cases, though, the role of the ESP teacher is misunderstood", a view which is also shared by Strevens (1988), Koh \& Wong (1990), Boyd (1991), among others. Nevertheless, the amalgam of circumstances highlighted make a case in favour of teachers of English for Specific Purposes overcoming their deficiencies so as to feel at ease and be confident (Chamberlain, 1980; Hutchinson \& Waters, 1984), not to mention that separating language from content is not always an easy task: "At higher levels, and especially at post-graduate level, $[\ldots]$ it becomes necessary to understand content if the language is to be effectively taught" (Kennedy, 1980: 122), a position that is equally stressed by Koh (1988: 76), "[...] language cannot be divorced from the thought it must express". It is necessary, therefore, to combine language and content.

To conclude, let us mention that ideally ESP teachers should have a twofold training in language and the content area of their students. However, the reality is that their ELT 
background warrants their competence as language consultants and as evaluators of the learning process of students, but does not provide them with proficiency in the content area. Therefore, they should keep up to date concerning both their training as ESP teachers and their students' field. Such aspects as their experience, whether they are native speakers of English or not, their knowledge about and interest in Social Sciences, Science, and Technology, and, finally, the immediate or non-immediate nature of purposes will determine the specificity of the course at issue (some of the factors which Kennedy [1980] stresses).

\section{Theoretical framework}

Although there is unanimity as regards the relevance of the collaboration between the ESP teacher and the content teacher, the positions on this score are both very general and difficult to put into practice. In the same way, in the field of ESP the student is seen as a collaborator, which_entails advantages and disadvantages that are also simply a theoretical reference.

With respect to the former type of collaboration, Hansen \& Hammen (1980) stress that team-working reduces the gap between science and language. Huerta, Ibáñez \& Kaulen (1986), as well as Schleppegrell (1991), coincide in showing that this is a way of resolving doubts about content. What, at first sight, might be an attractive idea, is not without its difficulties: dissimilitude of fields; different purposes, topics, and approaches; both teachers' conflicting timetables, and attitudes (Adams Smith, 1980). We should also consider, according to our personal experience, the interest on the part of content teachers in Business English, in this case, and their own competence in English (this latter aspect is positively stressed by Dudley-Evans \& St John [1998], who conceive it as the distinctive trait we should look for to establish this collaboration). In order to get round these obstacles, to some extent at least, Chamberlain (1980) points out that it is crucial that each of them knows what their role and attitude are towards learning from one another and collaborating.

In Dudley-Evans \& St John (1998) we detect a clearer specification of the content teacher's role in the field of English for Specific Purposes, that is to say, the role of collaborator with the ESP teacher. These authors base this collaboration on three progressive stages which they term cooperation, collaboration, and team-teaching.

The first is defined as the most simple phase, in which it is the ESP teacher who takes the initiative and enquires into the different subjects students are involved in, as well as into the tasks defining their target situation. Collaboration, on the other hand, implies a mutual interest on the part of both teachers, that is to say, each one draws on the other's experience with the common goal that both perspectives should be to the advantage of the students' education. This collaboration can adopt different formats: 
1) It is the content teacher who provides the topic which is the reference point (which these authors term carrier content) to introduce the linguistic side (which is called real content).

2) It is the ESP teacher, in this case, who prepares the students as far as language is concerned for them to have the necessary competence in academic or professional situations.

3) The content teacher guides the ESP practitioner as regards the topics selected by the latter.

4) Finally, team-teaching is the last of the stages we have referred to, in which each of the teachers focuses on their field, the ESP teacher on English skills and the content teacher on professional skills. As such, Koh (1988: 74) defines the role of language teachers as "supportive and subordinate", which explains that students consider their task as a side issue.

These four stages outlined by Dudley-Evans \& St John (1998) will serve as a reference point to analyze the collaboration I, as the ESP teacher, established with a teacher in the field of Public Management and Administration, when the former presented two English modules in a post-graduate course on Foreign Trade held at the University of Jaén in 2000.

If we now turn to the role of students as collaborators with the ESP teacher, there is no doubt that the former (whether they are experts in their field or trainees) are acquainted with the subject, whereas the ESP teacher normally is not. Obviously, authors such as DudleyEvans \& St John (1998: 13) distinctly sustain that "The teacher is not in the position of being the "primary knower' of the carrier content of the material"; a factor that, among some others, distinguishes ESP and GE (General English) methodologically, in that in the latter field the students do not have such a communicative role. Since the teacher is no longer the main source of information, the role of the teacher-student is seen as follows: "The student is in the driving seat. [...] the teacher draws on the student's own knowledge and 'fleshes' it out" (Hughes, 1999: 12); "Allow your students to put you right!" (Strevens, 1988: 43); just to mention a few coincidences of the literature on this score.

We should also add that the role of students as a source of information is not only limited to content matters, but also covers their target needs and, on some occasions, their learning needs. If we take the business world as an example, we can see it is defined as taking into account a wide spectrum of users and activities that, in most cases, show little similarity (Schleppegrell \& Royster, 1990; Robinson, 1991). This explains the students' role as collaborator so as to define the second type of needs so far referred to, mainly when we are dealing with non-deferred purposes in learning English: the students and the teacher have a different undertaking, as Tsaï (2000: 50) rightly stresses, "[...] teaching people in business is like a partnership where they [i.e. the students] are business experts, and you are the English expert". Nevertheless, this collaboration is not without its difficulties either (Dudley-Evans \& St John, 1998) because, although the teacher and the students alike can share the same view concerning target needs, they do not perceive deficiencies and learning needs in the same way. Our personal experience leads us to state that we should learn to 
listen to our students; analyze the validity of their views as regards the content of the English subject; not be afraid of being wrong because they are sometimes the experts in the topics we present to them so that we can justify what we do (which, more often than not, may not match their expectations), and opt to run certain risks (an attitude that in DudleyEvans \& St John's [1998] view warrants the effectiveness of ESP teaching).

This personal standpoint will be backed up from a practical perspective afterwards, aiming to show how this collaboration was implemented as far as the Foreign Trade course is concerned.

\section{A case study}

We start out by describing the teaching-learning situation that is the focus of our attention, because it is the reference point to analyze the features defining both the collaboration we established with a teacher in the field of Public Management and Administration and with our students, as well as to make the suitability of the ELT teacher as an ESP practitioner obvious. We were to present two English modules (each consisted of 15 hours) in a course on_Foreign Trade held at the University of Jaén. It was targeted towards students in the degrees from the Faculty of Social Sciences and Law Studies, as well as students holding these degrees, although not necessarily from that University, and the group would be relatively small, 15 participants.

All this led us to conclude that our students were experts in their field, and that if they had studied at the University of Jaén, most of them would probably not have studied English at university level - the 1995 syllabus of this Faculty does not include languages in any of its degrees -; and that probably the group would be heterogeneous regarding the level of linguistic competence and content area.

These expectations proved to be justified once the course started, confirming at the same time that, on the one hand, although there were mixed levels of language attitude, most students' entrance level was intermediate/upper intermediate; and, on the other, that there were non-immediate purposes in learning English. We could verify it by means of a needs analysis carried out during the first session of the first module. Our next step was to define the objectives of this course:

a) to train the professionals in handling the literature in their field to be up-to-date;

b) to enhance the writing skill in such ordinary tasks in the professional or academic field as the writing of business letters and e-mails and the elaboration of reports;

c) to enhance listening and speaking skills;

d) to train the students to comprehend and make themselves understood in three situations, that is, attending lectures, telephoning, and job interviews.

After this, we outlined the course contents, focusing now, primarily, on the reading and writing modules. We concentrated, in this respect, on intensive reading techniques such as skimming and scanning, extensive reading techniques (to read a case study about The Body 
Shop), reading speed, and ability to deduce the meaning of new vocabulary. Nevertheless, the intensive nature of the course demanded the selection of teaching materials - which Dudley-Evans \& St John (1998) call carrier content - in order to introduce these strategies, an aspect we underline because, obviously, at the same time it determines the collaboration of the content teacher.

In this respect, let us highlight that although it is not compulsory that the materials we present to our students be related to their content area, the fact remains that this assertion, largely documented in the literature, is excessively general, and that some specifications seem necessary. First, this will depend on the purposes for which the materials involved are used. By way of example, if we now centre on the module under scrutiny, it seems obvious, at first sight, that the selection of materials directly related to the students' field is a side issue as regards intensive reading skills. However, extensive reading a posteriori in case the students find it appropriate, could encourage the acquisition of new knowledge and a lexical enrichment in their field. Secondly, in our opinion, the previous statement is not quite consistent when we are dealing with extensive reading skills, not to mention other beneficial effects this relationship may exert (cf Almagro, 2001). Thus, as a first step, we needed to have a clear understanding of what the term Foreign Trade meant, along with some guidance about topics of interest.

As regards the writing skill, the course contents would be centred on the writing of a series of business letters in three fields: service offers, presenting a curriculum vitae, and commerce (letters of request for goods and services, and insurance); the writing of e-mails; the drafting of résumés; and, finally, the drafting of reports. In this sense, the ESP teacher with philological training, and with some experience in teaching English as a Foreign Language has a great deal to contribute to the ESP field. Our aims were: to cater for students' learning needs (showing them the usefulness of handling glossaries of business correspondence of similar characteristics, which can serve as a model in the target situation); the techniques of "cut and paste", which is why the use of connectors would also be considered; to familiarize them with the essentials of e-mails and reports, among other aspects, in order to facilitate their performance in the target situation. With this aim in mind, we made use of different sources to select teaching materials thematically related to the field of Foreign Trade and, by extension, of Management Internationalization, a point that we will take up later in the following section.

With respect to the listening and speaking skills, let us note that we had serious doubts about the professional situations on which to center them, since we trained students with non-immediate purposes in learning English. However, the students' collaboration was decisive in this respect, a matter that we will justify afterwards.

From the previous considerations, it can be inferred that those who are devoted to teaching English for Specific Purposes - and, as in our case, have philological training -, should not misconceive their role: to match learning needs with target needs and in order to do so we sometimes need the collaboration of the content teacher, as well as that of our students regarding specific aspects. All in all, our contention is that we can carry out our job competently, or as Koh (1988: 77) remarks: "[...] it is worth repeating that we are 
communication skills lecturers, and not subject teachers whose job is to further the students' knowledge of the subject". Next, we will analyze how the collaboration with the content teacher was implemented in respect of the aspects so far mentioned and some others that arose during the course, as well as with our students.

\section{Methodology}

The delimitation of the objectives of the two English modules, as well as of their contents, encouraged us to search for teaching materials. As we have already pointed out, neither the intensive nature nor the aims of the course favoured the use of a textbook.

The first obstacle encountered was that our scant knowledge about Foreign Trade hindered the selection of texts. As Dudley-Evans \& St John (1998) wisely stress, this type of drawback on the part of the ESP teacher favours the cooperation with the content teacher and, obviously, it is the former who fosters it due to the need to enquire into diverse issues. In our case, these mainly dealt with the meaning implied in the term Foreign Trade, and also with the contents defining the rest of the modules of this post-graduate course.

Thus, we got in contact with a colleague from the Faculty of Social Sciences and Law, and we mentioned to him the features of the course we were involved in, the objectives and the contents of the English modules, together with the information and help we needed.

His view revealed that, although the course was denominated as a post-graduate course on Foreign Trade, the content of the modules upon which it was structured implied a wider application than that of Foreign Trade itself. Some of the modules went deeply into some specific aspects pertaining to the latter stages of the process of Management Internationalization. However, the term Foreign Trade - economic activity based on the international trade of goods, capitals and services, which is carried out between a given country and the rest of the world and regulated by international rules and bilateral agreements (Ballesteros, 1998: 11) - is only one of the first stages of the company's international process.

This content nuance, unknown then by the ESP teacher, revealed that it would be convenient to investigate some crucial points to understand the whole process of Management Internationalization better. The content teacher informed us of the importance of addressing some previous questions because only in that way could we fully understand the modular structure of the course and its content. This seemed to be a main requirement for the students to take the fullest advantage of the English module. In this sense, it was appropriate to obtain information about the following issues:

1) What is meant by the process of globalization?

2) What is meant by internationalization of a firm?

3) And, finally, which are the stages of the process of management internationalization? 
In this sense, the following bibliographical references, selected by the content teacher, were crucial to understand these three issues: Llamazares (1999) with respect to the globalization process; Williamson (1975), Johanson \& Vahlne (1977), Dunning (1988), Welch \& Loustarinen (1988, 1993), Beamish (1990), and Melin (1992) as regards the meaning implied in the concept of internationalization of a firm; and, finally, Jarrillo \& Martínez (1991) regarding the stages involved in the process of management internationalization.

Once the foundations of management internationalization were set down, it became easier for us to understand the structure and content of the course modules, the main aims of which were: to provide students with a clear understanding of the current global and economic situation, as well as of the institutional framework of international relations; to show them the tools and sources of information available for them to appreciate the attractiveness of a foreign market; to let them see the implications of the term internationalization, as well as the different stages of development followed by any enterprise starting to expand internationally (these stages are occasional exports, experimental exports, regular exports, setting up of sales subsidiaries, and setting up of production subsidiaries overseas); and, finally, to make them familiar, on the one hand, with tariff, fiscal, civil, and mercantile laws and, on the other, with the commercial documentation and the financial and logistic instruments in use by those firms that find themselves in the first three phases of the internationalization process, that is to say, the foreign trade transactions in which firms are involved.

Our role at that point was clear. According to the aims of this course, the relevant areas which should lead to the selection of texts ought to be globalization, the institutional framework of international relations, the analysis of potential markets, the stages of the internationalization process, the instruments of foreign trade, and the fiscal, tariff, civil, and mercantile laws which regulate foreign trade. On the other hand, in the selection of texts we likewise had to take into account their suitability for our students' proficiency in English, as well as their extent and typographical appropriateness for presenting the different intensive and extensive reading techniques. Once we selected a great variety of texts pertaining to the relevant areas outlined above, we classified them according to the degree of linguistic difficulty, as well as the overall cohesion of the subject matter.

At this point, and building upon Dudley-Evans \& St John's (1998) view, cooperation led to collaboration. We now had to analyze with the content teacher whether the texts selected dealt with the thematic fields which centred on the rest of the modules, whether they exhibited thematic unity and progression and, finally, whether our students' knowledge of the topics presented matched their training.

There was a possible inference one might draw from the content teacher's point of view, this being that the selection of texts was somewhat unbalanced. In spite of the fact that the texts were about most of the themes of the course, we had not considered texts dealing with the different stages of the internationalization process. The content teacher was supportive of the view that the role of the English and professional skills would vary in terms of the stage of the internationalization process in which the firm was involved (see table 1). In this 
respect, we worked together to ascribe these stages to them, each of us building upon our own field of expertise, that is to say, while the content teacher delimited the activities defining the different internationalization stages, we matched them with the English and professional skills required.

Table 1

ENGLISH SKILLS AND PROFESSIONAL SKILLS IN THE FIRM'S INTERNATIONALIZATION PROCESS

\begin{tabular}{|c|c|c|}
\hline Internationalization stages & Listening/Speaking & Reading/Writing \\
\hline Occasional exports & $\begin{array}{l}\text { Telephoning } \\
\text { Negotiating }\end{array}$ & Corresponding \\
\hline Experimental exports & $\begin{array}{l}\text { Telephoning } \\
\text { Negotiating }\end{array}$ & Corresponding \\
\hline Regular exports & $\begin{array}{l}\text { Telephoning } \\
\text { Negotiating } \\
\text { Socializing }\end{array}$ & $\begin{array}{l}\text { Corresponding } \\
\text { Report writing }\end{array}$ \\
\hline Setting up of sales subsidiaries & $\begin{array}{c}\text { Telephoning } \\
\text { Negotiating } \\
\text { Socializing } \\
\text { Taking part in meetings } \\
\end{array}$ & $\begin{array}{l}\text { Corresponding } \\
\text { Report writing }\end{array}$ \\
\hline $\begin{array}{l}\text { Setting up of production subsidiaries } \\
\text { overseas }\end{array}$ & $\begin{array}{c}\text { Telephoning } \\
\text { Negotiating } \\
\text { Socializing } \\
\text { Taking part in meetings } \\
\text { Giving presentations }\end{array}$ & $\begin{array}{l}\text { Corresponding } \\
\text { Report writing }\end{array}$ \\
\hline
\end{tabular}

From the description of skills and contents of the English modules, briefly outlined in previous pages, it can be inferred that similarities and differences overlap in this respect. These are due to two different reasons: on the one hand, the progressive nature of the cooperation-collaboration we established with the content teacher, i. e., that the syllabus of the English modules was designed prior to the phase we are now describing; and, on the other, the students' own perception of their needs, a matter that led us to consider attending lectures and the job interview. Another aspect coming into play was that the intensive nature of the course was not conducive to the introduction of all the professional skills described in the previous table, although most of them were considered.

If we now turn to the thematic unity as well as the progression of the texts selected, we should point out that the content teacher's view corroborated their suitability. Moreover, he evidently noted that the understanding of these texts should entail no difficulty for students holding a degree in Law Studies or Business Sciences. Thenceforth, the final selection of texts was likewise implemented jointly, endeavouring to ensure their fullest content and linguistic suitability. 
If text selection demanded the content teacher's cooperation and collaboration as regards the aspects mentioned, a thorough reading of them gave rise to some doubts beyond lexical matters. In most cases, these doubts were due to the difficulty inherent in combining language and content, which were also resolved with the collaboration of this colleague. At the same time, some topics implied having to read up, at least from a general point of view, about subjects such as franchises, joint-ventures and subcontracting, which demanded cooperation once again. To this end, the content teacher provided us with some bibliographical references: Cuervo (1994) on franchises and Jarrillo \& Martínez (1991) on joint-ventures and subcontracting.

This collaboration went beyond. The content teacher gave us some texts (i. e. Nuevos vecinos en el zumo español [García, 1997]) we could present to our students and which he also used in the introduction to his Economía de la Empresa I lectures, specifically to explain the contents of the programme for the subject devoted to the company's growth, development, and international expansion.

Collaboration was also concerned with the implementation of a case study about The Body Shop at the end of the second module. Here our aim was twofold: Primarily, to integrate the four English skills starting from various activities that had been the focus of attention during this course (extensive reading enhancement by means of the data-gathering phase that the case called for, extensive writing when drafting a report about this firm's possible course of action, and listening and speaking skills enhancement via the meeting closing this case). Secondly, to devote the greater amount of time to oral and aural skills.

This case study, original in design, was prepared bearing in mind a hypothetical teaching-learning situation. As a result, when we thought about introducing it in this course, we analyzed its suitability for our present group of students, and also considered its every aspect with the content teacher. Our doubts centred on whether the scenario involved students in activities defining their target situation, and whether their competence corresponded to the professional skills required to take part in a meeting of this type.

Our collaborator thought that the choice of The Body Shop seemed to be a very good idea as it was about a company that had already reached the last stages of the internationalization process, so that it could be considered as a multinational enterprise. In his view, the choice of the case content was also appropriate, since the problem stems from an ambitious internationalization strategy. But, as the solution to the problem presented demanded the expertise of two different types of professionals (lawyers and economists) two profiles that exactly matched most of our students' training -, the content teacher suggested that we should state clearly the roles our students would assume, that is to say, of consultants and lawyers, instead of management consultants, as the ESP teacher had at first determined. This company required lawyers to deal with lawsuits brought by consumers against The Body Shop, and marketing specialists in order to restore the image its products had enjoyed up to that point and which had been seriously damaged.

In this sense, the content teacher's collaboration developed further when he provided us with a real solution to a case, since our contention is that ESP teachers should provide themselves with ample documentation before putting the case method into practice in the 
classroom. His recommendation was supported as follows: he mentioned he was acquainted with the case about the French multinational company Perrier, which bottles mineral water with natural gas, and which presented a similar problem to that of The Body Shop. Hence the advisability of reading up this case, so as to know the final outcome and the type of professionals required to resolve the situation.

This cooperation-collaboration could well have developed towards the third stage which Dudley-Evans \& St John (1998) call team-teaching, both teachers being present at the meeting about The Body Shop case and each of them assessing the students' competence to tackle the various issues involved: the ESP teacher concerned with language competence, and the content lecturer with the professional skills that work at meetings. However, this was not possible due to timetable constraints.

Finally, as regards the students' collaboration, we should point out that, in their view, the most immediate needs seemed to be, apart from understanding and making themselves understood, attending lectures, telephoning, and job interviews. We took their opinion into account, which was indeed sound. Its usefulness proved justified afterwards when three of them had a job interview, given that the main criterion guiding candidates selection would be their proficiency in English.

We should also add that our students frequently mentioned to us those aspects they were interested in, these being mainly related to learning needs. In short, they suggested we should provide them with glossaries of typical expressions used in business correspondence, as well as of specific vocabulary, and English grammars in order to extend their knowledge about some specific linguistic aspects. Moreover, they posed linguistic questions when they needed to, independently of the subject under scrutiny at that point during the course. Finally, we must not fail to mention that they always gave their opinion about the daily development of the modules we presented. Once again, it is evident that ELT teachers have a great deal to bring to the ESP field, in that their role is not always dependent on the content teacher.

\section{Conclusion}

To start with, regarding the role of students as collaborators, we should emphasize that this collaboration should be stressed, above all, when they have an immediate purpose in learning English or, as in our case, they have finished their studies at university level and their main aim at that moment is to gain access to a job. Nevertheless, some risks have to be run, and it is without saying that if we ask for their opinion we should take it into account.

On the other hand, the effectiveness of cooperation, collaboration, and team-teaching between the ESP teacher and the content teacher relies on the former's interest in the field of specialization of students, as well as on the latter's positive perception of the crucial role of English for training students, for example, in the field of Social Sciences, as well as of the content teacher's proficiency in English. It depends, finally, on the fact that neither of 
them misconceive their respective roles, in short: the ESP teacher's task is to define students' learning needs and assume the role of language consultant, while the content teacher is the provider of what Dudley-Evans \& St John (1998) term carrier content, as well as of professional skills consultant in different situations. In addition to this, the progression from cooperation to team-teaching is not only advisable but, obviously, a logical process, since reconciling such disparate fields as teaching business English as a foreign language and Social Sciences demands time and is no easy task. Equally worthy of mention is that team-teaching may lead to a fourth stage which could be called team-research, the present paper being positive proof of it.

\section{Notes}

1. Until quite recently, the general consensus was that the suitability of the ESP teachers should be stated in terms of their ability and experience in tailoring teaching materials (an aspect that Swales [1980] and Dudley-Evans \& St John [1988], among others, note). Nowadays, a fundamental shift is taking place, of which the two latter authors provide a clear exposition, when pointing out that this is but a myth of this field: although teachers may be skilled in tailoring materials, it becomes an impracticable task to personally design teaching materials to fit every teaching-learning situation. In these authors' view, the role of provider of materials brings together the three stages: selection, adaptation, and complementation.

\section{Works Cited}

Adams Smith, D. E. (1980): "Co-operative teaching: bridging the gap between E and SP". In Team Teaching in ESP (ELT Documents 106), 76-85.

Akermark, J. (1983): "Teacher training for ESP in adult education". The ESP Journal 2 (1): 39-41.

Almagro, A. (2001): "Rasgos que diferencian la enseñanza de ESP de la enseñanza de inglés general: ¿Una metodología diferente?". En S. Posteguillo, I. Fortanet and J. C. Palmer, eds., Methodology and New Technologies in Languages for Specific Purposes. Castellón: University Jaume I.

Ballesteros, A. (1998): Comercio Exterior. Teoría y Práctica. Murcia: Servicio de Publicaciones de la Universidad de Murcia.

Beamish, P. W. (1990): "The internalization process for smaller Ontario firms: A research agenda". In A. M. Rugman, ed., Research in Gglobal Strategic Management -International Business Research for the Twenty First Century: Canada's New Research Agenda. Greenwich: JAI Press Inc, 77-92.

Boyd, F. A. (1991): "Business English and the Case Method: a reassessment". TESOL Quarterly 25 (4): $729-734$.

Chamberlain, R. (1980): "The SP of the E". In Team Teaching in ESP (ELT Documents 106), 97108.

Cuervo, A. (1994): Introducción a la Administración de Empresas. Madrid: Civitas.

Cunningsworth, A. (1984): Evaluating and Selecting EFL Teaching Materials. London: Heinemann.

Donna, S. (2000): Teach Business English. Cambridge: Cambridge University Press. 
Dudley-Evans, T. and M. Jo St John (1998): Developments in English for Specific Purposes. Cambridge: Cambridge University Press.

Dunning, J. H. (1988): "The eclectic paradigm of international production: a restatement and some possible extensions". Journal of International Business Studies 19: 1-31.

ELT Documents 106. Team Teaching in ESP, 1980. London: The British Council Teaching Information Centre.

García, M. A. (1997): "Nuevos vecinos en el zumo español". El País, 12 de octubre.

Gueye, M. (1990): "One step beyond ESP: English for Developmental Purposes (EDP)". English Teaching Forum 28 (3): 31-34 and 38.

Hansen, A. G. and D. L. van Hammen (1980): "The English teacher and the camera - team teaching for special purposes". In Team Teaching in ESP (ELT Documents 106), 92-96.

Huerta, T., I. Ibáñez and A. Kaulen (1986): "Balancing institutional and motivational factors in ESP syllabus design". English for Specific Purposes 5 (2): 189-195.

Hughes, J. (1999): "Business English rods". English Teaching professional 12: 12-13.

Hutchinson, T. and A. Waters (1984): "How communicative is ESP?". ELT Journal 38 (2): 108113.

Jackson, J. (1998): "Reality-based decision cases in ESP teacher education: Windows on practice". English for Specific Purposes 17 (2): 151-167.

Jarrillo, J. C. and J. Martínez (1991): Estrategia internacional: más allá de la exportación. Madrid: McGraw-Hill.

Johanson, J. and J-E. Vahlne (1977): "The internationalization process of the firm- a model of knowledge development and increasing foreign market commitments". Journal of International Business Studies (Spring/Summer): 23-32. 11-24.

(1990): "The mechanism of internationalisation". International Marketing Review 7 (4):

(1992): "Management, foreign markets entry". Scandinavian International Business Review 1 (3): 9-27.

Jones, G. M. (1990): "ESP textbooks: do they really exist?". English for Specific Purposes 9 (1): 89-93.

Kennedy, C. (1980): "Fundamental problems in ESP". In Team Teaching in ESP (ELT Documents 106), 118-126.

Koh, M. Y. (1988): "The changing role of the ESL teacher and implications for ESP". In M. L. Tickoo, ed., ESP: State of the Art. Anthology Series 21. Singapore: SEAMEO Regional English Language Centre, 74-79.

Koh, M. Y. and I. Wong (1990): "A course in business communication for accountants". English for Specific Purposes 9 (3): 253-263.

Llamazares, O. (1999): Entorno internacional. Un Curso superior de estrategia y gestión del comercio exterior. Madrid: Consejo Superior de Cámaras de Comercio, Industria y Navegación de España, Instituto Español de Comercio Exterior.

Melin, L. (1992): "Internationalization as a strategy process". Strategic Management Journal 13: 99-118.

Robinson, P. C. (1991): ESP Today: a Practitioner's Guide. New York: Prentice Hall.

Schleppegrell, M. J. (1991): "English for Specific Purposes: a program design model". English Teaching Forum 29 (4): 18-22. 
Schleppegrell, M. J. and L. Royster (1990): "Business English: an international survey" . English for Specific Purposes 9 (1): 3-16.

Strevens, P. (1977): "Special-Purpose Language Learning: a perspective". Language Teaching and Linguistic: Abstracts 10 (3): 145-163.

. (1988): "The learner and the teacher of ESP". In D. Chamberlain and R. J. Baumgardner, eds., ESP in the Classroom: Practice and Evaluation (ELT Documents 128). London: Modern English Publications in association with The British Council, 39-44.

Swales, J. (1980): "The educational environment and its relevance to ESP programme design". In Projects in Materials Design (ELT Documents Special). London: The British Council, 61-70.

Tsaï, B. (2000): "Creativity". English Teaching professional 16: 50.

Voráèek, J. (1987). "ESP-superstructure and microlanguage". English for Specific Purposes 6(1): 53-56.

Welch, L. S. and R. Loustarinen (1988): "Internationalization: Evolution of a concept". Journal of General Management 14 (2): 34-55.

. (1993): "Inward and outward connections in internationalization". Journal of International Marketing 1 (1): 46-58.

Williams, R. (1981): "The potential benefits to the ESP profession from greater awareness of developments and practices in $\mathrm{L}_{1}$ communication skills teaching". The ESP Teacher; Role, Development and Prospects $90-95$.

Williamson, O. E, (1975): Markets and Hierarchies: Analysis and Antitrust Implications. New York: The Free Press. 